\title{
O fio de Ariadne: um mapa metodológico para a pesquisa de processos criminais como fonte histórica
}

\author{
Ariadne's Thread: a Methodological Map for Researching \\ Criminal Judicial Cases as a Historical Source
}

\section{Danielle Regina Wobeto de Araújo ${ }^{1}$}

Universidade Federal do Paraná - Curitiba/Paraná, Brasil daniius76@gmail.com

http://lattes.cnpq.br/4434684980998734

https://orcid.org/0000-0002-9747-3669

Gabrielle Stricker do Valle ${ }^{2}$

Universidade Federal do Paraná - Curitiba/Paraná, Brasil strickergv@gmail.com http://lattes.cnpq.br/6783144860180729 https://orcid.org/0000-0001-5640-4897

\begin{abstract}
Resumo: Este artigo visa auxiliar os operadores do direito, em especial os iniciantes, que tendo autos de processos criminais como uma de suas principais fontes históricas, pretendam desenvolver uma pesquisa em história do direito ou, mais pontualmente, em história da justiça criminal. $\mathrm{O}$ artigo está estruturado em três seções. A primeira é dedicada às reflexões metodológicas sobre o uso da fonte, que destacam
\end{abstract}

1 Doutora, com período de sanduíche na Scuola Normale Superiore di Pisa (SNS), e mestre em História do Direito pela Universidade Federal do Paraná (UFPR). Possui pós-graduação em Direitos Fundamentais pela Universidade de Burgos da Espanha e em Teoria do Direito e Direito Constitucional pela Academia Brasileira de Direito Constitucional (ABDConst). Professora de História do Direito e Pesquisadora integrante do Núcleos de Estudos sobre o Direito na América Portuguesa (NEDAP/UFC) e do Grupo de estudos Setecentistas do Núcleo de Pesquisa História, Direito e Subjetividade (Direito/UFPR).

2 Mestra na área de concentração de Direito do Estado, pelo Programa de Pós-Graduação da Faculdade de Direito da Universidade Federal do Paraná (UFPR), com bolsa CAPES-PROEX. É bacharela em Direito pela mesma instituição. 
suas principais características, potencialidades e problemáticas que podem ser abordadas. A segunda parte foi desenvolvida para orientar metodologicamente o pesquisador diante do caso concreto. Finalmente, na terceira, colocamos em prática algumas das precauções e argumentos tratados nas seções anteriores por meio da análise de processos seculares criminais de feitiçaria, tramitados na América Meridional Portuguesa do século XVIII, objetivando ilustrar como construir uma história cultural da justiça criminal que privilegie sujeitos marginalizados e seus direitos invisibilizados. Por fim, concluímos encorajando o uso crítico dos processos criminais, o qual pode interessar especialmente aqueles que compartilham uma perspectiva prática (sociológica) ou realista do direito.

Palavras-Chave: Arquivos; Metodologia; Historiografia; História do Direito; Feitiçaria.

AвSTRACT: This article aims to advise legal researchers, particularly beginners, who, having access to criminal cases as their main historical source, intend to research legal history or, more specifically, the history of criminal justice. We structure this article in three sections. The first focuses on methodological reflections on the use of this type of source, highlighting its main characteristics, potentialities, and the set of problems it allows us to address. The second part provides methodological guidance for the researcher when facing a specific case. Finally, in the third part, we put into practice the precautions and arguments discussed through the analysis of secular criminal cases of witchcraft, in XVIII century Portuguese South America, with the purpose of illustrating how to construct a cultural history of criminal justice that privileges marginalized subjects and their rights cast into invisibility. Finally, we conclude by encouraging the critical use of criminal cases, which may be of special interest to those who share a practical (sociological) or realist perspective on law.

KeYwords: Archives; Methodology; Historiography; Legal History; Witchcraft.

SUMÁRıo: Introdução: o processo criminal como labirinto; 1 Conhecendo o labirinto processual: reflexões metodológicas; 1.10 processo na historiografia; 1.2 A polifonia como característica; 1.3 A intensividade como característica; 1.4 O valor etnográfico; 1.5 O processo como disputa; 1.6. Barreiras historiográficas; 2 Mapa metodológico: atravessando o labirinto, armas e armadilhas; 3 Um labirinto já explorado: processos criminais de feitiçaria e a cultura colonial; Considerações Finais: sobrevivendo à travessia; Referências. 


\section{INTRODUÇÃO: O PROCESSO CRIMINAL COMO LABIRINTO}

A história do direito é um campo crítico de estudo relativamente novo que, não obstante, tem se mostrado pertinente para a compreensão do direito, da sociedade e de sua produção cultural. ${ }^{3}$ Desenvolver uma pesquisa em história do direito exige não só uma problemática jurídica, mas também a seleção de fontes históricas e a aplicação de uma metodologia adequada. A despeito disso - e das competências que a história do direito ajuda a promover - o ensino jurídico não costuma tratar do uso dos instrumentais necessários para desenvolver esse tipo de pesquisa, assumindo que sua compreensão seja generalizada pela prática jurídica.

Nosso contato com a história se dá no primeiro ano da faculdade, seja nas disciplinas de história do direito e de direito romano, seja ao longo do curso, nas aulas iniciais das dogmáticas jurídicas, as quais muitas vezes não se preocupam com a escrita da história. Nos manuais jurídicos e trabalhos acadêmicos, a história costuma aparecer em capítulos introdutórios, trazendo um panorama sobre determinado instituto ou categoria e em uma perspectiva bastante positivista, no sentido rankeano, acerca do que é história (FONSECA, 2009, p. 41; BOURDÉ, MARTIN, 1983, p. 97-117) - e até mesmo no sentido kelseniano do que é direito (SIQUEIRA, 2020; PEREIRA, 2006).

Apesar de, na maioria das vezes, estes estudos serem bem-intencionados, a ausência de fontes e metodologias próprias - que caracterizam as pesquisas de história - leva à naturalização, legitimação e celebração acrítica do direito vigente. Para rastrear o passado, especialmente o jurídico, é preciso explorar as especificidades do direito, ponto cego dos não-iniciados na arte. Reconhecer a historicidade das práticas e das categorias jurídicas ${ }^{4}$ é também um exercício de alteridade, pois o sentido da viagem ao passado, "não é a pesquisa do familiar, mas sim o confronto

3 O conteúdo de História do Direito constou nas diretrizes curriculares do curso de Direito com a Resolução CNE/CES n 9, de 29/09/2004.

4 Compartilhamos do entendimento de Antonio Manuel Hespanha (2010a, p. 14) acerca do uso do termo categoria ao invés de imagens, representações e conceitos. No caso em apreço, utilizamos o termo em razão de "remeter, na reflexão sobre o conhecimento, para ideia de modelos de organização das percepções, 'realidade' (...)”. 
com o diferente". Tomando essas premissas em nossas pesquisas, conseguimos relativizar o presente, contextualizar o direito corrente de modo a desnaturalizá-lo e colocá-lo na sua contingência e na sua provisoriedade histórica (COSTA, 2007, p. 17).

Dentre os diversos documentos contidos nos arquivos criminais, atentamos aos autos de processos criminais, particularmente, em virtude de sua finalidade jurídica e social - que é a averiguação do delito e sua correspondente autoria em prol da paz social - e de sua estrutura interna, integrada por diversas vozes, que possibilita examinar categorias, técnicas, argumentações e sensibilidades jurídicas na disputa judicial. ${ }^{5}$ Além disso, por viabilizar a recuperação de valores, regularidades e comportamentos sociais indistinguíveis em outras fontes, o processo oportuniza a verificação das engrenagens dos poderes e dos direitos - a censura, a discriminação e a marginalização de determinadas práticas sociais - dispositivos que são culturalmente mutáveis e obedecem a lógicas sociais e jurídicas complexas (CAULFIELD, 2000, p. 39-40; SBRICCOLI, 2020, p. 34-35).

Essa fonte histórica, cada vez mais disponível em repositórios virtuais, tem também a vantagem de se apresentar como uma farta documentação sobre fatos ainda "inéditos", quando não aqueles notórios, que merecem ser explorados pelos vieses da história do direito com o objetivo de escrever uma outra história, uma "história não única", de viés crítico (ADICHIE, 2019a, 2019b). Para nós, a reconstituição do passado jurídico por meio de processos criminais seculares de feitiçaria, que tramitaram no século XVIII, nas Vilas de Paranaguá e Curitiba, permitiu conhecer alguns aspectos da cultura jurídica-criminal colonial produzida e praticada por oficiais da justiça - letrados e não letrados - da América Meridional

5 Embora a documentação policial - em particular os inquéritos policiais também busque averiguar fatos delituosos e sua correspondente autoria, a historicidade de sua forma processual nos informa que esta não é uma fonte polifônica/dialogal tal como os processos criminais, porque não envolve um processo comunicativo tão complexo, bem como possui status jurídico mais precário (BRETAS, 1991; BRETAS; GRUNER, 2016). Isso pode ser dito, ao menos, até a recente promulgação de alterações no Código de Processo Penal e de legislação especial a respeito da participação da defesa durante a investigação criminal - o que pode dar um sentido diverso a esse momento pré-processual, até então entendido como inerentemente sigiloso, oficial, discricionário e inquisitivo. 
Portuguesa, como também acessar relações políticas, religiosas, sociais e de gênero (DEAP, 1735, 1763, 1773, 1775), conforme veremos em tópico específico mais adiante.

Entendemos que o esforço a ser desenvolvido pelo historiador do direito, ao lidar com os processos como fontes históricas, é semelhante ao de Teseu no labirinto construído por Dédalo e prisão do Minotauro: apenas o fio de Ariadne é capaz de nos guiar para a saída. Premido pelas formas jurídicas - que, de imediato, parecem todas iguais ou levar às mesmas encruzilhadas - nós pesquisadores devemos reconhecer que estas oferecem caminhos variados e resultados igualmente distintos. $\mathrm{O}$ desafio do labirinto, ou melhor, do processo, nos leva ao encontro mortal com a fera semi-humana - que, aqui, podemos entender como a dupla temporalidade encerrada nos autos dos processos: parte animalesca e mitológica, representando a impossibilidade de conhecer os fatos exatamente como se deram; parte fruto da orientação racional do juiz a uma resolução do conflito.

Considerando que os processos tomam forma na/pela justiça, ou seja, em um ambiente no qual o direito "não depende apenas da capacidade de cada jurista para pensar, imaginar e inventar, mas de um complexo que envolve, no limite, toda a sociedade, desde organização da justiça, à sensibilidade jurídica dominante e muito mais" (HESPANHA, 2005, p. 27-28), tomamos, neste texto, a história do direito como história da justiça. Por conta disso, entendemos que o "processo social de produção do próprio direito" é mais bem explicado pela "perspectiva sociológica de mais curto alcance, que relaciona os efeitos (culturais, discursivos) com uma dinâmica específica de espaço (ou nível e instância) social particular em que eles são produzidos" (HESPANHA, 2005, p. 28). Por outras palavras, desconsiderando modelos universais e determinantes.

Para quem estuda o período anterior à constituição do Estado de Direito (modernidade jurídica), tal concepção se faz imprescindível, dada a falta de autonomia do direito em relação a outras ordens normativas. Para períodos posteriores, a história do direito pode tomar o direito em uma das três perspectivas clássicas de análise - a filosófica, a normativa e a sociológica (BOBBIO, 2018). Em nossas pesquisas, temos explorado o direito, por meio da dimensão sociológica e prática do direito (SABADELL, 2017, p. 250), já que é na justiça que o significado e a efetividade 
do direito são disputados e definidos e, por esse motivo, justifica-se a importância do processo como fonte.

Aliás, para quem estuda o período colonial brasileiro, como nós, torna-se imprescindível compreender a história do direito de forma ampla. Afinal,

se entre os letrados, a teoria social e política estava contida na teoria da jurisdição e da justiça, para os leigos, a mais visível expressão da ordem social e do poder era a administração da justiça nos tribunais. Por isso o processo e a parafernália dos Tribunais (rituais, cerimonias, fórmulas) eram tidos como constituindo o modelo mais fiel do exercício do poder político. (HESPANHA, 2005, p. 32-33)

Amparadas nessas premissas e tendo em vista as potencialidades e as especificidades da fonte histórica, apresentamos aos operadores jurídicos - especialmente os iniciantes - um mapa do labirinto, no qual desenrolamos o novelo e puxamos alguns fios sobre reflexões historiográficas e metodológicas acerca do processo criminal para a produção de uma história do direito/da justiça criminal crítica.

\section{ConHECENDO O LABIRINTO PROCESSUAL: REFLEXÕES METODOLÓGICAS}

1.1 O processo na historiografia. Em linhas gerais, recordamos que, no Brasil, o processo criminal - analisado quantitativa ou qualitativamente - foi difundido como fonte histórica nos anos de 1980, em virtude da história cultural, que aproximou a História e a Antropologia. Não por acaso, verifica-se, na historiografia brasileira do período, o grande impacto das obras de Thompson, Foucault, Ginzburg, Natalie Davies, Michelle Perrot, entre outros (GRINBERG, 2009, p. 127; DANTAS; NICOLETTI, 2020, p. 51-66). Como veremos adiante, foram acirrados os debates acerca do uso de tal fonte para produção de uma história social dos vencidos e do direito.

1.2 A polifonia como característica. Um dos principais argumentos apontados pelos defensores do uso de processo criminal como fonte histórica é a polifonia que lhe é inerente. Uma fonte dialógica ou polifônica, 
resumidamente, é uma fonte integrada por diversas vozes que dialogam em decorrência da própria maneira como estão estruturadas ou, ainda, em função dos próprios objetivos que as materializam e que, por isso, permitem elucidar relações interindividuais e entre os grupos sociais. Podemos no dialogismo dos processos criminais, acessar diferentes versões que estão em conflito, alcançar "as visões de mundo que os atores sociais encaminham uns contra outros, as redes de rivalidades e solidariedades que daí emergem, as identidades e preconceitos" (BARROS, 2012, p. 12).

Alertamos, porém, que o diálogo entre os personagens que estão na disputa judicial e que estão autorizados a falar nesses textos não se encontram em um mesmo nível comunicativo. Ginzburg pontuou a esse respeito que, embora inquisidor e réu se situem no plano do discurso como duas vozes de igual ecoar, estão, em verdade, em situação de desigualdade. E é essa desigualdade em termos de poder (tanto real quanto simbólico) que explica um dos motivos pelo qual a pressão exercida pelos inquisidores sobre os réus - para extrair a verdade que eles estavam procurando - era, usualmente, bem-sucedida. No sentido de decifrar o processo criminal, estamos obrigados, então, "a aprender a captar, por baixo da superfície uniforme do texto uma interação sutil de ameaças e temores, de ataques e recuos. Devemos aprender a desenredar os diferentes fios que formam o texto factual desses diálogos" (GINZBURG, 1991, p. 15).

1.3 A intensividade como característica. O processo criminal, além de polifônico, é uma fonte intensa, ou seja, uma documentação que existe por causa do "desejo de verdade" (GINZBURG, 1991, p. 12) de instituições e de seus agentes, a qual é definida por um escopo. Se a finalidade jurídica do processo é a reconstrução dos fatos que lhe deram causa para apuração da "verdade", esta é uma fonte caracterizada por estar repleta de narrativas e detalhes a esse respeito.

Essa intensividade, à luz do método indiciário, que privilegia o exame dos detalhes e pormenores em detrimento da generalidade, penetrando nas "coisas concretas e ocultas através de elementos poucos notados ou desapercebidos, dos detritos ou 'refugos' da nossa observação” (GINZBURG, 1989, p. 147), facilita detectar não só os aspectos jurídicos e da vida concreta, mas também daquela vida imaginária, composta de relatos do cotidiano, dos ambientes de sociabilidade e das diversas sensibilidades (medos, crenças, esperanças, rivalidades) presentes nas relações 
sociais (BUENO, 2013, p. 1-12; GINZBURG, 1989, p. 147; GINZBURG, 2011a, p. 19-20). O processo criminal, portanto, se bem documentado e rico em fatos ou personagens, privilegia um exame qualitativo, em particular por meio da metodologia da micro-história, na qual, quanto mais detalhes, mais possibilidades para compreensão do passado (VAINFAS, 2011). Não à toa, essa análise exige também um esforço de compreender a fala de um "outro” (GINZBURG, 1991, p. 14).

1.4 O valor etnográfico. Essa busca de compreensão “do outro" requer uma atitude antropológica, entendida como disposição dialógica de nós, pesquisadores, diante do confronto entre culturas diferentes. Aliás, foi essa procura que: (i) deslocou o olhar dos historiadores das instituições repressoras para os invisíveis e marginalizados da história; (ii) direcionou a produção historiográfica para o discurso, para o cotidiano e para as práticas culturais, além de incluir novos sujeitos históricos vencidos e excluídos - e; (iii) levou a uma alteração da escrita da história (conhecida como história cultural).

A polifonia e a intensividade são, portanto, algumas das principais características do processo criminal como fonte histórica, as quais o tornam uma fonte complexa e com destacado valor etnográfico, que nos obriga a ter habilidades metodológicas que outras fontes não exigem, tais como desenvolver filtros axiológicos que nos orientem na análise dos valores envolvidos em cada dimensão dos discursos existentes nos processos, como também precisamos de filtros técnicos relativos ao direito, ou seja, devemos conhecer as reflexões, regras e as práticas relativas às instituições, às categorias, aos ritos, aos procedimentos, à própria linguagem jurídica, aos operadores jurídicos, entre outros aspectos (GINZBURG, 1991, p. 15).

1.5 O processo como disputa. A compreensão do processo como fonte histórica requer também que tenhamos em mente que cada instauração de processo criminal representa o começo de uma batalha judicial, na qual cada parte e seus representantes buscam que suas versões jurídicas sobre os fatos prevaleçam perante uma autoridade julgadora:

Na sua materialidade, o processo penal como documento diz respeito a dois 'acontecimentos' diversos: aquele que produziu a quebra da norma legal e um outro que se instaura a partir da atuação do aparelho repressivo. Este último tem como móvel o objetivo de estabelecer a ‘verdade' da qual resultará a punição ou a absolvição 
de alguém. Entretanto, a relação entre processo penal, entendido como atividade do aparelho policial-judiciário e dos diferentes atores, e o fato considerado delituoso não é linear, nem pode ser compreendida através de critérios de verdade. Por sua vez, os autos, exprimindo a materialização do processo penal, constituem uma transcrição/elaboração do processo, como acontecimento vivido no cenário policial ou judiciário. Os autos traduzem a seu modo dois fatos: o crime e a batalha que se instaura para punir, graduar a pena ou absolver. (FAUSTO, 1984, p. 21)

Desse modo, observamos que nós, pesquisadores, precisamos estar preparados para manejar duas instâncias que se imbricam no processo criminal como arquivo: "a) as tensões e as lutas que estabelecem o bojo das articulações intrínsecas à lógica processual, institucional e do Direito; b) os complexos processos sociais que se 'materializam' nos autos e estão à mercê da interpretação por parte do historiador" (ROSEMBERG; SOUZA, 2009, p. 169).

Devemos, portanto, tomar a estrutura interna dos processos-crime como um processo - ou seja, como uma tentativa de construção da verdade, ou, ao menos, da verossimilhança - em torno de um caso de quebra das leis penais e normas sociais (ROSEMBERG; SOUZA, 2009, p. 128). Logo, necessitamos também estarmos alertas diante da possibilidade de distorção das falas pelos mediadores (operadores jurídicos) - não à toa designados pelos antropólogos de "manipuladores técnicos" - já que atuam a partir de suas representações sociais e buscam ordenar a realidade de acordo com as representações sociais eleitas pelo Estado. Essa crítica feita aos operadores jurídicos, tidos como "manipuladores técnicos" é rebatida por Ferrajoli (2002, p. 48), quando o jurista italiano afirma que:

Os documentos interpretados pelo historiador, da mesma forma que as provas 'documentais' em sentido estrito, utilizadas também no processo, são, contudo, como se disse, preexistentes à investigação e não já constituídas no curso dessa investigação. Está claro que a circunstância de que a maior parte das fontes

6 Termo cunhado e popularizado na historiografia por Mariza Corrêa (1983, p. 40); a concepção do termo foi seguida por outros antropólogos (FAUSTO, 1984, p. 22-23). 
judiciais, ao revés, seja produzida para a investigação dos fatos a que alude, e não antes e independentemente dessa investigação, aumenta os condicionamentos subjetivos, seja pela maior implicação emocional dos sujeitos dos quais provêm, seja pelo maior interesse no êxito da investigação que sobre elas pode pesar. Em compensação, as provas judiciais podem apresentar, precisamente por sua natureza 'artificial', uma maior autenticidade. O processo é, por assim dizer, o único caso de 'experimento historiográfico'. Nele, as fontes são funcionalizadas ao vivo, não apenas porque são recebidas diretamente, mas também porque são confrontadas entre si, submetidas a exames cruzados e chamadas a reproduzir o evento julgado, como em um psicodrama.

1.6 Barreiras historiográficas. Ponderando os argumentos acima, entendemos a crítica de que o processo é uma fonte escorregadia, em especial quando se busca escrever uma história dos vencidos e excluídos. Todavia, entendemos que, ainda que de maneira indireta e enviesada, é possível extrair da linguagem técnica, dos discursos e das práticas jurídicas, as tensões, as atitudes, as visões de mundo, as experiências, as "circularidades culturais" (GINZBURG, 2006) - enfim, um conjunto de atributos culturais - dos atores sociais envolvidos no processo judicial. Compete a nós pesquisadores, portanto, "a tarefa árdua e detalhista de desbravar o seu caminho em direção aos atos e às representações que expressam, ao mesmo tempo que produzem, estas diversas lutas e contradições sociais" (CHALHOUB, 2001, p. 41-42).

Ademais, sendo o direito dotado de historicidade, ele não flutua na história e na sociedade, mas está fundamentalmente integrado a ela, merecendo ele próprio uma apurada análise a ser empreendida especialmente pelos juristas e historiadores do direito, pois é aí que reside a sua especificidade:

O direito não é escrito numa paisagem física que aguarda ainda o inserir-se humano, mas é escrito na história, na grande ou na pequena, que, dos primórdios até hoje, os homens constantemente teceram com sua inteligência e seus sentimentos, com seus idealismos e seus interesses, com seus amores e seus ódios. É no interior dessa história construída pelos homens que se coloca o direito, ali e somente ali. Realidade dos homens, mas realidade plural (...) O direito é de fato uma dimensão intersubjetiva, é relação entre 
vários sujeitos (poucos e muitos) e é marcado pela sua essencial socialidade. (GROSSI, 2006b, 2008; destaque do autor)

Aliás, pelo olhar da história do direito, verificamos que muitos dos argumentos usados para criticar o uso de processos criminais para a produção de uma história social dos vencidos decorre de uma visão bastante moderna do direito - positivista e formalista - na qual ele se resume a um ato da autoridade estatal (que se manifesta pela lei, pelo ato administrativo e pelas sentenças judiciais).

Efetivamente, o campo jurídico, especialmente na modernidade, busca representar certos esquemas organizativos de valores da sociedade que se consolidam em regras e institutos, convertendo-se, por fim, em um esquema lógico, que será aplicado pelas instituições através de seus operadores do direito; na justiça, em especial, pelos juízes diante de um caso concreto. Entretanto, essa visão acaba se mostrando excludente, pois desconsidera o pluralismo jurídico predominante no passado e invisibilizado no presente.

Daí que seja também tarefa de nós pesquisadores do direito esclarecermos do que se trata a experiência jurídica em determinado período da história para os demais campos do saber e abordagens históricas. Foi e é pela falta desse diálogo interdisciplinar que muitas pesquisas do campo do direito não são consideradas pelas humanidades (NOBRE, 2009, p. 4 e 6).

Apesar de cada vez mais recorrente o uso de processos criminais, seja na história ou na história do direito, ${ }^{7}$ uma parcela da historiografia jurídica ainda despreza a produção de uma história do direito que possua como principal fonte histórica o processo judicial, particularmente, o criminal. É o que se infere do texto de Sbriccoli (2020, p. 25-41), originalmente publicado em 1988 e recém traduzido para o português, no qual o historiador, a pretexto de elencar os problemas no uso da fonte

7 Atualmente, alguns estudos da história global e que privilegiam a interseccionalidade (CRENSHAW, 2002) recorrem aos processos criminais com fonte histórica, tal como a história de "Páscoa Vieira, diante da Inquisição. Uma escrava entre Angola, Brasil e Portugal" (CASTELNAU-L'ESTOILE, 2020). Essa fonte histórica, também vem sendo cada vez mais explorada na história no direito tanto para estudos que privilegiam o exame quantitativo como para a análise qualitativa (PEREIRA, FURMANN, 2013; ARAUJO, 2016; PAES, 2019; BRIGHENTE, 2019; SILVA, 2020). 
por historiadores sociais, critica, de um lado, o quantitativismo e a assunção de pressupostos típicos do paradigma etiológico e, de outro, a case history - associando a ela riscos como o de uma história beletrística, fascinada por "episódios impressionantes" ou "pouco usuais" (sejam eles com "alto grau de representatividade", "bom poder de representação" ou sejam eles excepcionais frente ao funcionamento rotineiro da justiça).

O historiador explicita sua desconsideração das fontes arquivísticas ao dizer que "o processo é mudo" e que, por isso, só pode ser lido em perspectiva comparada. Em consonância com essa posição, entendemos que o autor italiano privilegiou, intencionalmente, a análise do conteúdo do direito penal em sua categoria denominada de "penal", embora a conceitue como "experiência jurídica em sentido amplo: positiva/substancial e processual, doutrinária e normativa" e de "todos os momentos relevantes da prática da repressão: da prevenção (quando existe) à pena, passando pelo julgamento" (SBRICCOLI, 2020, p. 34). Há, embutida nessa posição, forte rechaço ao estudo da administração judiciária e do que ele chama de "direito ritual", o qual se faz acompanhar também da acusação de renúncia de análise do elemento jurídico dos autos, frente ao que sobraria tão somente o seu lado "ideológico" ou "antropológico". Entendemos, no entanto, que Luigi Lacchè (2020, p. vi) buscou atenuar o conceito de "penal" proposto por seu mestre, se voltando para o valor etnográfico de suas fontes e considerando também "[...] a práxis judiciária; a processualidade do direito penal, ou melhor, o entrelaçamento, por muito tempo, insolúvel entre a dimensão prática do enforcement e o desenvolvimento dos princípios substanciais; [...]".

No nosso sentir, diante do atual estágio da produção historiográfica, as críticas promovidas por Sbriccoli se tornaram despropositadas e excludentes, pois reduzem o direito a uma concepção "cientificista", nos termos de Pietro Costa (2011), típica do liberalismo moderno, no qual a doutrina produzida pelos "intelectuais, os homens do poder, os homens dos aparatos" (SBRICCOLI, 2020, p. 39) seria a fonte mais adequada - senão a única - para a produção da história do direito e do direito

8 Segundo o autor, "conjunto das regras (ou das práticas) que, em relação às instituições judiciárias, disciplinam as competências e o procedimento" (SBRICCOLI, 2020, p. 35-36). 
criminal. Não por outro motivo, Sbriccoli (2020, p. 36-37) considera que seu objeto de estudo tenha um período naturalmente "privilegiado", entre os séculos XVIII e XIX, com a absorção da doutrina penal dos juristas e a criação do Estado.

Aludida posição diante das fontes judiciárias ignora, de uma única vez, a multiplicidade de jurisdições estabelecidas em ambientes de pluralismo jurídico, fenômeno historiográfico globalmente localizado (glocalized) antes da modernidade, e superdimensiona a importância da produção bibliográfica e legiferante perante os valores sociais efetivamente aceitos pela população, mesmo após o advento do Estado de direito. É por isso que aquilo que Sbriccoli (2020, p. 32) entende por uma história "árdua e arriscada" parece-nos, apesar de todas as críticas e observados os pressupostos que reunimos, uma história da justiça que vale a pena ser escrita e que, substancialmente, tende a concordar com as mesmas ponderações críticas a respeito das reais funções da justiça criminal.

Como nosso propósito não é estreitar as análises sobre o passado, e conhecer o direito apenas pela doutrina (tradição jurídica) ou pelas regras elaboradas por uma elite de homens, entendemos que o processo é adequado porque dá voz a sujeitos marginalizados e direitos invisibilizados. Isso porque os autos já representam, juridicamente, a ocorrência da quebra de uma norma social, sendo excelente fonte para a produção de uma história social-criminal-jurídica, que examine questões que envolvam a criminalidade, e/ou para a produção de uma história cultural-criminal-jurídica, especialmente, se na fonte encontrarmos "personagens fronteiriços” (pessoas, casos/fatos/eventos, locais e direitos) (GINZBURG, 2006, p. 19-25) e ela for rica em argumentos jurídicos e estratégias processuais. Assim, ao lado da grande duração, das estruturas, do quantitativismo de viés sociologizante, somos também favoráveis a uma abordagem cultural, de escala reduzida, que dá voz aos sujeitos e que se centra na qualidade da documentação (GINZBURG, 2011).

Em nossas pesquisas com os processos criminais do período colonial, verificamos que, apesar do pensamento jurídico e das regras jurídicas do período moderno terem conferido poucos momentos de fala direta dos excluídos - as noções de contraditório e ampla defesa são mais contemporâneas que modernas - e mesmo cientes de que os discursos e teses jurídicas apontam apenas para uma das possíveis versões 
dos comportamentos sociais, além de materializarem discursos e teses produzidos para responder às expectativas do "Estado", entendemos que os processos criminais e a atuação de seus operadores fornecem material adequado para uma história do direito - especialmente para aqueles que tomam o direito como prática e/ou em perspectiva teórica realista (LOPES, 2021; MACCORMICK, 2008; HART, 1994; HESPANHA, 2009; FERRAZ JR, 2007).

Em síntese, superando questões epistemológicas da representação; ultrapassando o fator da objetividade da fonte em virtude dos "manipuladores técnicos” e; tendo noção da historicidade do direito, como saber e como prática, é construir uma outra história do direito ou da justiça possível a partir de processos criminais, que contemple não só questões jurídicas, mas também de gênero, etnia, classe e crença.

\section{Mapa METOdológICO: ATRAVESSANDO O LABIRINTO, ARMAS E ARMADILHAS}

Apresentamos, então, um mapa com alguns dos principais pontos em debate e cuidados metodológicos, na expectativa de que guie e facilite os operadores jurídicos iniciantes em explorar o processo criminal como fonte histórica em suas pesquisas.

2.1 Tomando os processos criminais como um conjunto ordenado de documentos (autos), uma primeira tarefa que se impõe é reconhecê-los. Devemos conhecer seu suporte material, seu idioma, sua forma textual, o tipo de vocabulário e o padrão da documentação. Nesse momento, nós, pesquisadores, especialmente aqueles que trabalham com fontes anteriores ao século XIX, devemos estar preparados para enfrentar uma documentação possivelmente incompleta, manuscrita e materializada em um "outro" português, características essas que exigem noções de paleografia e a companhia de dicionários de edições históricas - sejam de teor linguístico, médico, jurídico, entre outros.

Ainda, se faz interessante conhecer o contexto de produção e a trajetória no tempo, ou seja, saber como a documentação chegou até os dias atuais. Alertamos que em hipótese alguma devemos olvidar que os registros nos processos criminais são compostos de "rostos e sofrimentos, emoções e poderes criados para controlá-los”. (FARGE, 2009, p. 94). 
Nesse compasso, sublinhamos que as fontes produzidas pelas polícias, como inquéritos policiais, em períodos históricos de exceção merecem uma postura crítica e uma maior sensibilidade, de modo que não devemos esquecer que tais documentos, regra geral, foram criados e lavrados de maneira arbitrária - e até mesmo violenta - visando incriminar e calar sujeitos que se insurgiram contra o Estado (BAUER, 2009, p. 186-187). ${ }^{9}$

Para nós, que trabalhamos com processos criminais de feitiçaria da época moderna, foram oportunas as reflexões de Ginzburg contidas no texto "O Inquisidor e o Antropólogo", em que o historiador italiano traça a história da apropriação - por protestantes, católicos e liberais dos processos criminais como fontes históricas e nos mostra o aumento de interesse por uma abordagem cultural em detrimento daquela social, até então prevalecente. ${ }^{10}$ Conhecer a apropriação das fontes da Inquisição Portuguesa por abordagens historiográficas diferentes pode auxiliar nas problemáticas de pesquisa daqueles que trabalham com processos seculares e eclesiásticos ou com temas e categorias jurídico-criminais relativos ao período colonial (ARAUJO; VALLE, 2019).

2.2 A tarefa de reconhecimento também exige que nos aproximemos ainda mais da estrutura do processo criminal para entendermos a sua dinâmica interna e como os operadores o articulam, bem como

9 Para quem pretende trabalhar com fontes da ditadura brasileira, recomendamos também a leitura das reflexões produzidas pelos estudos que envolvem história e memória como também a metodologia da história oral.

10 Houve resistência dos historiadores protestantes, que queriam enaltecer seus antecessores ou enfatizar a perseguição católica; de outro lado também houve resistência dos historiadores católicos, que não queriam aceitar que membros do catolicismo empreenderam torturas e outras violências; também houve resistência de historiadores liberais, que consideravam as provas de bruxaria fornecidas em julgamentos como um misto de extravagâncias teológicas e superstições populares. Acerca dos processos de bruxaria, registra Carlo Ginzburg, que por muito tempo houve relutância por parte dos historiadores em usar aludida fonte. Os historiadores consideravam que as provas de bruxaria vindas de tais processos eram uma mistura de extravagâncias teológicas e superstições populares, que eram por definição irrelevantes. Porém, tal quadro se alterou, a bruxaria da periferia passou para o centro das questões históricas. Tal valorização decorreu da crescente influência da antropologia na história. Destacam-se acerca do tema as obras de Evans-Pritchard, que influenciou na história Alan Macfarlane e Keith Thomas (GINZBURG, 1991, p. 205, 2006, p. 19). 
para compreendermos as peças jurídicas e as práticas que se estabelecem em diferentes ocasiões, tal como investigação, inquérito, torturas, instrução, julgamento e fase recursal ou extraordinária. Ademais, tendo em vista que, nos processos criminais, as partes e os fatos são narrados e registrados pelos agentes autorizados (juiz, advogado de defesa e acusação, escrivão ou cartorário), nos é imprescindível também conhecer, no plano normativo e no doutrinário, quem são e quais seus poderes e suas atribuições legais, como também quais relações jurídicas estabelecem ou como participam no processo.

Em toda essa etapa, é fundamental compreender a finalidade do processo criminal no ordenamento jurídico e a concepção de direito/ justiça do período histórico, acerca do qual a pesquisa se desenvolve. Isso sem perder de vista que "não existem fatos criminais em si, mas que há um julgamento que os funda e um discurso criminal que os fundamenta" (GRINBERG, 2009, p. 128). Por consequência, precisamos estar cientes não só das normas do direito penal - que estabelecem os atos proibidos, ou crimes, aos quais são atribuídos penas ou castigos - como também das normas do direito processual criminal - que regulamentam "o modo como um crime é investigado, as formas de comprovação de verdade (provas e testemunhos) e os critérios de tomada de decisões judiciais. É nesse campo que se determinam as regras de andamento dos processos criminais.” (GRINBERG, 2009, p. 122). Não basta só isso: também se faz indispensável conhecer as normas que disciplinam as instituições responsáveis pela administração da justiça.

Em realidade, para se fazer história do direito/da justiça a partir de processos criminais, não basta ter apenas um conhecimento instrumental e normativo do direito, é preciso conhecer os institutos, os conceitos, as regras e os debates doutrinários jurídicos e a jurisprudência que orientam o direito criminal e processual, uma vez que essas questões constituem o cerne da pesquisa em história do direito; e facilitam a interpretação dos processos criminais tomados como fonte histórica primária da pesquisa. Para José Reinaldo Lima Lopes, é preciso ter conhecimento técnico e domínio para compreender a linguagem específica típica do campo processual, como quando nós, juristas, "falamos em jurisdição, competência, natureza das ações, dos provimentos e sentenças, das condições de admissibilidade dos recursos e assim por diante" (LOPES, 2017, p. 12). 
Dessa forma, se estivermos inteirados das normas que regem o processo criminal, cai por terra a distinção entre processo e procedimento - já ultrapassada entre juristas - mas que ainda contamina os historiadores do direito. O processo é conhecido, dentre várias construções, como uma relação abstrata entre as partes, mediada por um juiz e determinada por princípios como o contraditório e a legalidade processual (os quais articulam o devido processo legal); enquanto o procedimento seria o mero encadeamento temporal entre atos formais, normalmente escritos. Sob os pressupostos dessa discussão, alguns historiadores do direito tendem a argumentar que, para o período anterior à modernidade jurídica, não se fala do processo propriamente dito, mas do procedimento - que seria, portanto, arbitrariamente determinado pelas autoridades e de conteúdo juridicamente inócuo.

Consideramos tal posição equivocada, uma vez que: (i) parte do pressuposto de que seja possível encontrar a gênese primeira do processo judicial tal como é pensado nas democracias contemporâneas, atravessado pelos princípios que o dotam de racionalidade jurídica; (ii) ignora as formulações teóricas realizadas pelos próprios juristas da época em estudo para justificar a realização do procedimento de uma forma ou outra qualquer, bem como a aderência (ou não) dos demais operadores jurídicos a tais formulações; (iii) por consequência, busca uma distinção de nomenclatura que não encontra eco nas fontes históricas; e (iv) acaba por desprezar a riqueza de conteúdos que se pode extrair dos autos de um processo - ou procedimento, como se queira chamar -, ignorando a possibilidade de produção normativa por parte dos operadores jurídicos (CANTISANO; PAES, 2021; SIROTTI, 2021, p. 459).

2.3 Além de estarmos cientes das regras que regulamentam o processo criminal e os agentes que nele atuam, conforme já mencionamos, precisamos estar atentos à questão metodológica que envolve a compreensão das vozes ou, nos termos de Farge (2009), a "captação das vozes", e das mensagens internas transportadas no processo.

Como vimos, o processo criminal é uma fonte polifônica/dialógica e intensa, logo devemos não só identificar e descrever as vozes que interagem na comunicação do processo criminal, como considerar os seus pontos de aproximação e afastamento, notando as mediações que lhes são impostas. 
Perceber polifonias, no entanto, não é uma tarefa tão simples; e mais complexa ainda é a busca de dialogismos implícitos, pois, embora a própria estrutura do texto registre explicitamente a voz do outro, muitas vezes tais estruturas são sabotadas e, assim, ao invés de privilegiarem o diálogo, registram um monólogo (BARROS, 2012, p. 26). Na Inquisição Moderna, muitos juízes-inquisidores - acreditando estarem salvando os pecadores do inferno - estavam autorizados por lei a fazer perguntas ambíguas ou retóricas, que já comportavam respostas ou que possibilitavam certos padrões de respostas e não outros.

Por causa dessas particularidades, associadas a outras já tratadas aqui, é que os historiadores do direito devem ter uma postura crítica com relação aos registros feitos pelos operadores jurídicos, especialmente juízes e cartorários, mesmo estando eles balizados na tradição jurídica. Devemos - sempre e como primeira tarefa - questionar seus interesses "em relatar com veracidade, o que viram ou ouviram, em registrar com maior ou menor rigor os depoimentos que recolheram”, e seus objetivos em dar voz aos vencidos, ou não (BARROS, 2012, p. 26).

Devemos estar atentos também ao momento da transcrição de procedimentos orais para a forma escrita, pois de modo geral, há redução das variadas manifestações verbais e gestuais ao texto escrito, que torna o "discurso adstrito a padrões de estilos e sintaxes desenvolvidos no âmbito mesmo da processualística” (ROSEMBERG; SOUZA, 2009, p. 166). Vale dizer, depoimentos do réu ou das testemunhas são remetidos e limitados por um vocabulário e por conjunto de regras altamente formalizadas - as normas de processo penal - que é a linguagem do judiciário.

2.4 Dessa maneira, é necessário também termos em conta que a emissão de um depoimento é uma forma de construção de verdade - tal como o processo como um todo - que pode ser distorcida pelos operadores jurídicos desde a captação até o registro, bem como pode ser influenciada por questões e símbolos periféricos ao ato, como as condições arquitetônico-ambientais e as diferentes liturgias das instituições. Tudo isso é relevante porque o ato de julgar é um evento no espaço e no tempo, de modo que o campo simbólico do rito processual ${ }^{11}$ mediatiza o contato

11 “'Realizar um rito é fazer qualquer coisa com a força', escreve Paul Ricoeur, que com estas palavras, nos deu, porventura, a melhor definição do rito que 
do juiz com a realidade e prepara os demais atores do processo para a "experiência estética da justiça” (GARAPON, 1997, p. 17-26).

Assim, a arquitetura, os símbolos, os rituais, e as vestimentas das justiças também devem ser considerados por nós, pesquisadores, como instrumentos de mediação, já que são estranhos a maioria da população, impactando em seus depoimentos (FERRAJOLI, 2002, p. 48). Podemos imaginar o quão inibidor era dar um depoimento perante a Inquisição, normalmente instalada em edifícios sagrados e de espaço hierarquizado. Para se ter uma ideia, a Inquisição Portuguesa no Regimento de 1640, no título 2 do Livro 1, dispunha até mesmo como deveriam ser os cárceres para os acusados de heresia. Diferentemente das outras cadeias, essas eram construídas e pensadas de forma a privilegiar o silêncio e, com isso, tornar mais fácil o exame de consciência e, consequentemente, a extração da confissão (ARAUJO; VALLE, 2019; INQUISIÇÃO, 1996).

2.5 Superada a fase de reconhecimento da constituição e da operacionalidade do processo criminal como fonte histórica, que aumenta significativamente nossa consciência histórica sobre a documentação e consequentemente sobre a nossa pesquisa, passamos a examinar o teor de seu conteúdo, de suas mensagens, que podem: "\{comover, divertir, manipular, seduzir, persuadir, impor, estabelecer, mover, paralisar\} através dos depoimentos que instauraram discursos específicos" (GRINBERG, 2009, p. 121-122) e, acrescentamos, através das peças elaboradas pelas partes e autoridades oficiais.

Nesta etapa de exploração do conteúdo dos autos de processo, devemos aclarar os elementos sociais dos personagens envolvidos na trama do crime e suas relações sociais. Chalhoub (2001, p. 41-42) recomenda que, diante da fonte, devemos agrupar as várias vozes segundo critérios de afinidade - classes sociais, relações de solidariedade, rivalidade ou

se conhece. Sem força, não há poder; eis porque é que as duas histórias do político e do simbólico são inseparáveis. A força capta-se, afasta-se e conserva-se dificilmente. O símbolo associa, daí a necessidade de reconstituir essa cadeia de associações que o torna significativo. Mas trata-se de um material difícil de trabalhar, dado apresentar falsas continuidades, semelhanças enganosas e uma polissemia desconcertante. Esta permanência de fachada está repleta de armadilhas, já que um mesmo reportório simbólico não parou de ser solicitado em sentidos diferentes" (GARAPON, 1997, p. 26). 
preconceito; gênero; crenças; condições jurídicas etc. - a serem definidos pelo problema histórico-jurídico que está orientando a pesquisa e a reflexão historiográfica. Através de uma boa descrição da ação dos funcionários da justiça e de certos padrões da vida cotidiana dos indiciados contidos em ocorrências criminais, Boris Fausto (1984), por exemplo, reconstruiu valores, representações e comportamentos sociais da São Paulo da virada do século XIX para o XX.

No âmbito da história do direito ou da justiça criminal, também devemos verificar, no caso concreto, quem são os operadores jurídicos pode ser útil conhecer o ambiente de formação jurídica (institucional ou não), bem como o quadro docente, os cursos ou disciplinas ministrados e as obras disponíveis nas bibliotecas - e como desempenharam suas funções no que se refere ao processo e ao crime apurado no processo. Associado a isso, recomendamos uma identificação e análise de suas relações e redes de poder, e, se possível, de micropoderes. Como vimos, a vontade de verdade das autoridades que conduzem o processo possibilita que se conheça, além das regras, os valores e a cultura de diversos grupos sociais que fundam os Códigos (modernos ou não) ${ }^{12}$ e/ou que operacionalizam a justiça criminal nas mais altas (letrados) ou baixas (não-letrados/práticos) instâncias da justiça.

12 Código: a palavra é utilizada desde a antiguidade, mas com outra concepção. O atual significado é produto pós-revolucionário e representa a valorização da razão escrita. Os códigos publicados a partir do século XIX têm como características: (i) colocar em prática a razão iluminista (universal e abstrata) que confiava nos preceitos positivados; (ii) representar a vontade do povo (poder legislativo); (iii) organizar e modelar/prescrever/conformar a sociedade; (iv) no lugar do casuísmo, sua lógica é da subsunção; (v) instaurar o monismo jurídico (unifica os direitos civis) e o absolutismo jurídico (lei como principal fonte), e; (vi) pretender a eternidade, logo é tido como a-histórico. As Ordenações, como consolidações, apenas organizavam os reinos e tornavam os costumes mais "certos e previsíveis", não podendo, desse modo, serem vistas como um Código, como um instrumento real empregado para fins de centralização do poder com a consequente redução do pluralismo jurídico. De acordo com Luís Fernando Lopes Pereira (2008), as normas contidas nas Ordenações não visavam impor o que Paolo Grossi denominaria de absolutismo jurídico, ou seja, a consolidação da lei - produto da vontade geral - como a principal fonte do direito. Em suma, os objetivos das Ordenações eram totalmente diferentes dos pretendidos pelos Códigos elaborados no século XIX, que reduziam ao Estado, um ente estranho e superior a sociedade, o poder de legislar. 
Devemos nos ater à gramática, à lógica, à técnica, à racionalidade, aos argumentos e ao pensamento jurídico contido em todas as peças que constituem o processo. Se fizermos isso, veremos que o debate jurídico e a prática processual criminal prevaleciam sobre os debates de direito criminal no período anterior ao do Estado de Direito, em que o princípio da legalidade não se expressava de forma vinculativa e, por consequência, sem o reconhecimento forte do atributo da tipicidade. O caractere definidor do delito seria, essencialmente, a prática de uma conduta contrária ao direito revelado, sendo injusta perante aquela comunidade. A depender da jurisdição, o elemento moral da antijuridicidade ressaltava espécies de dolo, com graus e significados distintos de vontade e consciência dentre os quais ficou especialmente conhecido o dolus malus (ARAUJO; VALLE, 2018, p. 28-31, 47-49).

E isto não se deu sem razão, uma vez que a primeira categoria a suscitar questões em torno do conceito de delito surgiu do processo criminal: o corpo de delito (corpus delicti ou Tatbestand), consistente no "conjunto de elementos de que se compõe o delito, abrangendo assim em seu conteúdo a antijuridicidade, a culpabilidade e a materialidade do fato criminoso" e que permitia, por consequência, a aplicação da pena (MARQUES, 1950, p. 31-32; BRANDÃO, 2014; BUSATO; CAVAGNARI, 2017). Foi devido a esse conceito que, em 1906, Ernst von Beling realizou a distinção moderna entre conduta delituosa e tipo penal, dividindo a noção de injusto em descrição objetiva do crime (tipo) e em conteúdo objetivo-valorativo (antijuridicidade), além do elemento descritivo-subjetivo (psicológico) da culpabilidade (BUSATO, 2018, p. 204-206, 437440). Entendemos que isso não teria ocorrido se o direito canônico não tivesse debatido a respeito da teoria das provas e indícios a ser aplicada pelos juízes, de modo que o conceito jurídico de crime já foi intimamente vinculado à história do processo e da justiça criminal.

Portanto, não sendo suficiente o "sentido social político" que o processo é capaz de mobilizar em seu conteúdo, mesmo sob a aparência do formalismo (ARAUJO; VALLE, 2018, p. 50-51, 60-61, 74, n. 127), ressaltamos, como possível objeto de análise do pesquisador, as adaptações contínuas e os eventuais desencontros entre as finalidades do processo e a estrutura conceitual do direito penal. O caso particular do delito de feitiçaria, por exemplo, é exemplar da prática de um delito sem vínculo 
causal-natural, o que foi teoricamente admitido em matéria penal até o século XIX, quando então seu fundamento moral seria esvaziado na jurisdição secular e o crime se tornaria impossível.

Se pretendemos fazer, associada à história do direito, também uma história social, devemos desvendar as alegações e as razões das partes nos processos, especialmente, ao narrar o cotidiano e as sensibilidades compartilhadas por sua comunidade. Paolo Grossi (2006a, p. 124) afirma que muitas vezes, além de produzirmos uma história jurídica, também desenvolvemos ou recorremos à história social. Por conta disso, Sbriccoli (2019, p. 310) entende que o historiador do direito deve possuir a dupla competência de jurista historiador e historiador da sociedade. Isto é, o historiador do direito é um ser bilíngue que também deve falar a língua da história.

Outra dúvida que nós, pesquisadores, temos diante do processo criminal como fonte histórica é se devemos, ou não, escrever o contexto dos fatos e dos direitos mais próximos e também o mais amplo, que fundamenta a sociedade e define os seus grandes horizontes, dos quais nenhum dos personagens consegue escapar. O tema é polêmico nos debates historiográficos; para Ginzburg, por exemplo, a escrita do contexto é apenas opcional, pois em realidade ele deve atravessar o exame das fontes e dialogar com elas em jogo de escala. ${ }^{13}$

13 De um lado, temos Ginzburg que critica aqueles que fazem do contexto algo imprescindível para história, como faz, por exemplo, Natalie Davis (GINZBURG, 2011a, p. 355). De outro lado, temos o texto de Dominick LaCapra, que tece diversas críticas a obra $O$ queijo e os vermes e que, no seu ver, contém e sintetiza todas as vantagens e desvantagens das tendências da profissão do historiador. As tendências são "uma inclinação a apoiar-se em uma definição social de contexto como uma matriz explanatória; uma guinada em direção a um interesse pela cultura popular; uma reconceitualização da cultura em termos de discursos coletivos, mentalidades, visões de mundo, e mesmo 'linguagens'; uma redefinição da história intelectual como o estudo dos significados sociais historicamente constituídos; e um realismo documental arquivístico, que trata os artefatos como jazidas de fatos na reconstituição das sociedades e culturas do passado" (LACAPRA, 2005, p. 295). Apesar dos avanços, para o historiador estadunidense, muitas das pretensões elencadas tendem a se tornarem ambíguas "quando engendram sociocentrismo dogmático, populismo metodológico, a recusa em reconhecer a significância histórica de aspectos excepcionais da cultura e uma compreensão ultrassimplificada da linguagem 
O caso por si só não se explica e, como não se pretende permanecer na mera narrativa, há que se estabelecer ligações com o contexto. São exatamente tais conexões que permitirão a leitura de um caso como anômalo (em relação à norma). A anomalia traz em si a norma, daí a maior relevância de seu estudo, pois a análise da norma, ao contrário, não nos permite apreender a anomalia. (PEREIRA, 2012, p. 37)

Para arrematar, no momento de análise do crime, não podemos esquecer, conforme já visto, que o processo criminal em sua materialidade, como autos, "é uma encruzilhada de muitas lutas" (CHALHOUB, 2001, p. 41-42), pois envolve dois tipos de acontecimentos diversos: o fato inicial que gerou a transgressão da regra (o crime) e que, por si só, já é um fenômeno que enreda múltiplos fatores; e a linha temporal que se instaura a partir da atuação da justiça com o objetivo de estabelecer a "verdade" da qual resultará a punição ou absolvição; e que cada ato e procedimento registrado nos autos, corresponde, no limite, a ações isoladas, cujo fio condutor se perdeu.

Como quer que seja, para a produção da história do direito/da justiça criminal, mais do que compreender o que efetivamente ocorreu entre as partes, devemos perceber a finalidade do processo como um todo, verificar as versões e desvendar os significados nas relações jurídico-sociais estabelecidas nos autos. Vale dizer, devemos identificar a forma (como) pela qual os discursos e as práticas se articularam diante das possibilidades jurídicas existentes. Assim, capturamos e construímos uma história jurídica cultural. Esta perspectiva não prejudica ouvir as vozes da sociedade e dos “criminosos” sob julgamento, pois é possível superar as teses, posturas, perspectivas e estratégias subjacentes ao embate jurídico e social e assumidas por personagens que representam e constituem a justiça (ROSEMBERG; SOUZA, 2009, p. 168), como visto ao longo deste artigo.

e do significado, frequentemente acompanhada de um uso redutivo de textos e documentos" (LACAPRA, 2005, p. 295). 


\section{UM LABIRINTO JÁ EXPLORADO: PROCESSOS CRIMINAIS DE FEITIÇARIA E A CULTURA COLONIAL}

Com base nas reflexões historiográficas e orientações metodológicas acima, exploramos alguns processos criminais de feitiçaria que tramitaram na justiça secular das Vilas de Curitiba e Paranaguá no século XVIII, ou seja, na justiça régia dos confins da América Meridional Portuguesa, com o objetivo de contribuir na produção de uma história da cultura jurídica colonial criminal.

Apesar deste estudo ter como foco processos criminais de feitiçaria que tramitaram na justiça régia, não podemos perder de vista que o contexto jurídico do período colonial época era de multinormatividade - ou, em outros termos, do pluralismo político-jurídico (DUVE, 2017; HESPANHA, 2005). O pluralismo jurídico da época moderna pode ser compreendido como a coexistência social de ordens normativas distintas (com legitimidade e conteúdos diferentes), sem que existissem regras fixas e sistematizadas que delimitassem, previsivelmente, o âmbito de vigência de cada ordem jurídica. Ademais, nesse sistema havia uma prevalência da doutrina (tradição jurídica) sobre a lei como fonte do direito, especialmente na prática jurídica. O pluralismo jurídico do período se contrapõe, portanto, ao paradigma legalista-estatal surgido no século XIX, que tem como principal fonte do direito a lei estatal, a qual é alçada ao status de dispositivo conformador e civilizador da sociedade (COSTA, 2006, p. 102; HESPANHA, 2005, p. 118).

Por conta disso, podemos dizer que a feitiçaria se caracterizava por ser uma categoria normativa múltipla, vale dizer, era tanto um delito (dissidência social), estipulado nas Ordenações do Reino, a ser julgado pela justiça secular, como também um pecado fixado nas Constituições de diversos Arcebispados - inclusive no da Bahia, no século XVIII - e a ser julgado pela justiça eclesiástica, ou uma heresia (desvio da ética e dos dogmas da fé) de jurisdição da Inquisição, conforme previsto no título 14, §5º do Livro 3 do Regimento de 1640.

Do ponto de vista institucional, o uso dos processos criminais de feitiçaria - associado a outras fontes, como atas camarárias, eleitorais e da almotaçaria ${ }^{14}$ - permitiu concluirmos que a justiça secular na

14 Instituição prevista nas Ordenações do Reino, que remonta ao período mouro, mas que permaneceu após a reconquista católica, provavelmente, em 
região estava organizada nos termos das Ordenações do Reino, ou seja, em Câmaras Municipais e Ouvidorias. Essas instituições funcionavam em uma lógica jurídica diferente da atual, sem que fizessem sentido os princípios da tripartição dos poderes, da legalidade, da superioridade normativa da constituição e, por conseguinte, sem operar com a noção de direitos fundamentais.

A Câmara Municipal - presidida e constituída por um ou dois juízes, vereadores, almotacéis, cartorários ou outros oficiais - tinha seus ofícios públicos ocupados por "homens bons", ou seja, proprietários eleitos por outros "homens bons". Apesar dessa constante, também conseguimos observar que o exercício de tais ofícios significou mobilidade e ascensão social para alguns membros da população, que em tese e por lei estavam proibidos, como era o caso dos comerciantes (ARAUJO, 2011, 2016).

Notamos também que, mesmo não possuindo formação jurídica, alguns oficiais camarários, com o decorrer do tempo, desenvolveram habilidades técnico-jurídicas e as utilizaram, inclusive, em benefício do poder local em detrimento do poder da Coroa - esta, representada pela Ouvidoria, que ficava em Paranaguá. Luís Fernando Lopes Pereira analisou a atuação de Francisco de Siqueira Cortes, que foi juiz ordinário da Vila de Curitiba por dez vezes, e verificou que, no início de suas atividades como juiz, apenas assinava despachos, formais e concisos. Porém, com o decorrer do tempo, passou a despachar de próprio punho e a assinar seu nome de forma mais rebuscada (PEREIRA, 2008, p. 43).

A Ouvidoria, como instituição judiciária de segunda instância na região, também estava devidamente organizada em torno de oficiais reinóis letrados, que cumpriam funções administrativas, legislativas e judiciárias. Aos Ouvidores, coube traduzir e "vulgarizar"15 o direito contido

virtude de seu viés moral, que visava ordenar e disciplinar as cidades e as populações do período colonial (ARAUJO, 2011).

15 O direito vulgar, resumidamente, consiste em uma visão e percepção menos técnica e mais popular do direito. O conceito foi elaborado por Otto Brunner que verificou como se deu a sobrevivência do direito romano no período medieval. Acerca da vulgarização do direito, recomendamos a leitura do artigo de Bernal (1994), que explica tal categoria no âmbito da América Espanhola. Para a América Portuguesa, o tema pode ser localizado nos debates entre rústicos e letrados, minuciosamente analisado por António Manuel Hespanha (2010b). 
nas Ordenações mediante Provimentos, redigidos em uma linguagem mais acessível para a população, mas também para os oficiais camarários (ARAUJO, 2016). Os Provimentos levaram o direito da Coroa para mais próximo de seus súditos e instituições, especialmente quanto "ao seu formato, às suas representações roupagens e procedimentos”. Não à toa, os Ouvidores são considerados promotores de um "intercâmbio entre uma linguagem própria (jurídica) possuidora de técnica específica e ritos regulamentados e a rusticidade das vilas brasileiras". (PEREIRA, 2008, p. 26)

Do ponto de vista social e de gênero, visualizamos a estratificação e a hierarquização da sociedade colonial nas fontes, determinando inclusive a configuração estabelecida entre as partes processuais em virtude do próprio acesso à justiça pelos “homens bons”. Sempre tivemos, de um lado, um querelante ou denunciante reclamando que suas propriedades - mulheres, escravos e imóveis - foram enfeitiçadas por mulheres indígenas e/ou mestiças administradas e, de outro lado, escravas indígenas que se tornaram rés em autos criminais. Efetivamente, o fato de ser mulher e descendente da população indígena ou da africana, em conjunto com a condição jurídica imposta (de administrada ou escrava), muitas vezes bastou para incriminar e condenar alguém como feiticeira (ARAUJO, 2019).

No fundo de todas as denúncias e delações contra as feiticeiras, estavam o patriarcalismo, a misoginia e a intolerância a crenças não católicas. A despeito do fato que essas denúncias autorizassem, como estabeleciam as normas, que o juiz ou o Ouvidor recorressem a torturas e até fixassem a pena de morte às feiticeiras coloniais, elas não foram aplicadas. Entendemos que a Vila de Curitiba, como a maioria das Vilas coloniais da América Meridional Portuguesa, dependia da feitiçaria para a promoção de curas e para explicação das mazelas da vida, motivo decisivo para que juízes proferissem mais absolvições ou degredos do que outras penas, como a "morte natural".

Do ponto de vista da cultura jurídica, os processos criminais nos mostraram que, apesar dos procuradores das rés e dos réus não possuírem formação jurídica acadêmica - chamados de rábulas ou "práticos" - estes conheciam as formalidades do direito e do processo, de modo a desenvolverem bem suas funções de defesa. O mesmo pode ser dito a respeito dos promotores, que não eram letrados, e exerciam outras funções na Câmara. 
As petições estavam todas elaboradas na forma de artigos, como mandava as Ordenações do Reino, e em diversas passagens os rábulas recorriam a argumentos de autoridade sintonizados com a melhor doutrina criminal da época moderna. Essas referências variavam entre teólogos, juristas, textos bíblicos e pagãos, além de diversos trechos em latim que remontavam a períodos mais remotos e clássicos do direito (ARAUJO, 2016).

Um dos autores identificados foi Prospero Farinacci, um importante criminólogo italiano do século XVI, que teve sua obra bem recepcionada em Portugal, onde se elaborou um manual, para os inquisidores portugueses, totalmente ancorado nas suas lições. ${ }^{16}$ Outro autor identificado foi Martín Del Río, teólogo espanhol cuja obra teve muita circulação em Portugal em razão de orientar juízes, mas que foi banida por Pombal. Além desses autores, Cícero foi citado para reforçar que a função da defesa era auxiliar o juiz na leitura dos fatos. Conforme escreve António Manuel Hespanha (2015, p. 145-146), o autor foi um dos clássicos mais bem recepcionados por autores cristãos, influenciando o pensamento jurídico e político.

O uso de tal literatura nas peças jurídicas de processos criminais de feitiçaria, contudo, deve ser lido sem perder de vista que se tratava de fundamentos jurídicos extraídos de livros praxistas (ARAUJO, 2016; CABRAL, 2017). Quer dizer: não significa que os operadores jurídicos tivessem acesso físico ou conhecimento profundo a respeito dos textos clássicos da cultura jurídica e teológica erudita, mas também não significa que não possuíssem quaisquer noções sobre seu conteúdo. A forma com que os autores são citados na petição, associado às condições em que os rábulas atuavam, nos permite concluir que mesmo nos confins da América Portuguesa, os livros práticos de direito circularam e constituíram a formação de seu público (ARAUJO, 2016).

Ainda do ponto de vista da cultura jurídica criminal, notamos a estratégia de absolvição das rés, por parte de seus procuradores, com a busca de provas de sua religiosidade, dada a natureza do crime de feitiçaria. Para tanto, alegavam a educação católica, o comparecimento às missas, bem como recorriam a testemunhos com peso comprobatório

16 ARQUIVO NACIONAL DA TORRE DO TOMBO (ANTT). Tribunal do Santo Ofício, Inquisição de Lisboa, Livro 78. 
superior, tal como o de um cristão-velho. Os rábulas promoviam também a "desqualificação" dos delatores e de outras testemunhas de acusação, recorrendo, especialmente, aos argumentos de pobreza e de raça, que estavam juridicamente atrelados a pessoas menos dignas e confiáveis.

De uma perspectiva processual, eram frequentes os pedidos de nulidade dos processos criminais por falta de cumprimento dos requisitos jurídicos. Em um dos processos examinados, verificamos que um dos procuradores pediu a nulidade por não ter a acusação juntado um laudo de corpo de delito, o qual era lavrado por médico ou exorcista e comprovaria o nexo causal entre a morte e a suposta conduta criminosa da feiticeira, tal como recomendava a melhor doutrina e a jurisprudência dos Tribunais.

Também nos interessou o exame da construção da verdade pelos agentes autorizados a atuarem nos processos, ou seja, como o discurso criminal funcionou e como nele se operaram as diversas mediações. Levando em conta que as regras de processo criminal no século XVIII conferiam pouca voz aos acusados, percebemos que, nos momentos de inquirição das feiticeiras e de suas testemunhas, juízes e tabeliães atuaram dentro de seus poderes normativos e dentro dos moldes formulários das Ordenações e Provimentos. As inquirições, portanto, foram diretas e não se caracterizaram como dúbias ou incriminadoras, tal como ocorria e era permitido na Inquisição.

Atentamos, todavia, para o fato de que, em um dos autos de processo-crime, o juiz não tenha se interessado por uma delação indicativa da ocorrência de idolatrias em um suposto "cartório de feiticeiras", que ocorria na casa de uma mulher proprietária. O desinteresse comprova a tese de que a justiça secular estava mais preocupada em apurar o dano causado pelo ato maléfico do que em investigar as crenças, tarefa precípua das justiças inquisitorial e eclesiástica na América Portuguesa. Ainda assim, devemos registrar que as menções ao Diabo estiveram mais presentes nas vozes das autoridades, dos denunciantes e dos delatores do que nos próprios depoimentos das feiticeiras. Uma delas - por sinal, Januária, a mais sábia - disse que até via o Diabo, mas que com ele não conversava (ARAUJO, 2016).

Podemos dizer, dessa maneira, que a particularidade do direito colonial foi a própria circularidade cultural, também manifestada, no 
caso especial da feitiçaria, pelo sincretismo religioso entre as noções do magismo popular e do satanismo teológico. Dito de outro modo, as particularidades jurídicas não nos levaram a uma cultura "informal" ou "rústica" da justiça criminal, mas a uma cultura prática pautada em interpretações das normas do direito régio, que eram ou reforçadas ou adaptadas conforme os interesses jurídicos ou políticos locais, dando novo sentido ao direito.

Com base na análise dos processos criminais de feitiçaria pudemos concluir que a cultura jurídica criminal e processual criminal colonial estava situada entre a erudição jurídica escolástica deglutida pelos manuais praxistas e a adaptação prática dos crimes e do procedimento processual na América Meridional Portuguesa.

Além disso, o direito produzido pelos oficiais e práticos (não-letrados) no juízo ordinário da Vila de Curitiba notabilizou-se pelo diálogo com os Ouvidores (letrados) da Vila de Paranaguá, e não por ser opor a ela. Ora reforçando o direito régio, ora os interesses da elite, a prática jurídica colonial permitia que "interesses locais patrimonialistas e trocas de favores em redes de favorecimento [fossem] escondidas sob uma roupagem jurídica com a chancela d'el Rei." (PEREIRA, 2008, p. 23). Portanto, a partir dos processos criminais de feitiçaria, reforçamos a noção de que a justiça criminal é um fenômeno cultural que pode - e deve ser - analisado por essa perspectiva metodológica.

\section{Considerações Finais: sobrevivendo À travessia}

O presente texto teve o propósito de apresentar um mapa com algumas das principais reflexões e orientações metodológicas acerca dos processos criminais como fonte histórica, especialmente, para os operadores do direito poucos habituados a encarar o labirinto processual e a refletir sobre o direito a partir de uma perspectiva da história.

Apontamos, em um primeiro momento, as principais reflexões e características que potencializam o processo criminal como fonte: a polifonia, a intensividade e o valor etnográfico. Esperamos ter deixado claro que, apesar da relutância historiográfica quanto ao seu uso para a produção de uma história dos vencidos - o que em nossa visão inclui uma 
história da justiça criminal diferente daquela prevista nas normas e/ou praticada pela elite jurídica - a questão parece ultrapassada e superada, sobretudo se observarmos a atual produção historiográfica.

Em um segundo momento do texto, elaboramos um mapa do labirinto, que teve como objetivo apresentar as armas e evidenciar as armadilhas que o pesquisador iniciante pode encontrar ao tomar o processo criminal como fonte histórica. Sublinhamos a necessidade inicial de reconhecer, na fonte, o seu contexto de produção, as regras e a doutrina de direito criminal e processual que instauram e norteiam o processo, bem como estarmos cientes das regras que regulamentam as instituições envolvidas e organizam a administração da justiça na qual os processos tramitaram.

Somente após tomarmos uma consciência mais crítica da documentação é que recomendamos o exame de seu conteúdo e das mensagens que o processo transporta sobre o crime. Mais do que compreender o que efetivamente ocorreu entre as partes, entendemos necessário perceber a finalidade do processo como um todo, desvendando, nas versões apresentadas pelas partes e aceitas pelo juízo, os significados das relações jurídico-sociais estabelecidas. Vale dizer, devemos identificar como os discursos e as práticas se articularam diante das formas jurídicas condicionantes e das possibilidades existentes.

Vimos que tal perspectiva não prejudica nossa "audição" e compreensão das vozes da sociedade e dos réus sob julgamento, pois é possível colocá-las em um plano de análise para além das teses, posturas, perspectivas e estratégias subjacentes ao embate jurídico-social, as quais são assumidas por personagens que representam e constituem a justiça, como visto ao largo deste artigo. Desse modo, outras jurisdições, direitos, sujeitos e práticas podem ser retirados da invisibilidade histórica a que foram submetidos, tornando muito mais complexo o cenário jurídico e o da história do direito criminal.

Amparadas nessas mesmas premissas, analisamos os processos feitiçaria que tramitaram numa vila "insignificante" - como tantas outras e, justamente por isso, significativa - da América Portuguesa, no século das luzes (XVIII). Com o auxílio dos processos criminais, junto a outras fontes provenientes do Juízo ordinário de Curitiba e da Ouvidoria de Paranaguá, conseguimos não só recuperar o espaço institucional, com 
os seus principais agentes camarários, mas apresentar uma outra história jurídica da cultura jurídica colonial criminal, bem diferente daquela que só enxerga, no passado, as Ordenações Filipinas ou a tradição jurídica. É justamente nesse aspecto que o historiador do direito pode contribuir, pois uma abordagem crítico-jurídica ajuda em construções e desconstruções históricas não apenas jurídicas, considerando a distância entre teoria e prática no direito, mas também socioculturais.

Em síntese, encorajamos a pesquisa com processos criminais, em acréscimo a outras fontes, pois permite romper generalidades típicas de grandes sínteses, que se apartam de sujeitos subalternizados e de certos aspectos jurídico-culturais que acrescentariam novas percepções a respeito da cultura jurídica criminal e processual criminal.

\section{REFERÊNCIAS}

ARAUJO, Danielle Regina Wobeto de. Feitiçaria na vila de Curitiba: direito e misoginia (XVIII). Revista Direito e Práxis, Rio de Janeiro, v. 10, p. 222-249, 2019. https://doi.org/10.1590/2179-8966/2018/31930

ARAUJO, Danielle Regina Wobeto de. Um “Cartório de Feiticeiras": direito e feitiçaria na Vila de Curitiba (1750-1777). Tese (Doutorado em Direito) - Universidade Federal do Paraná, Curitiba, 2016. https://acervodigital.ufpr.br/handle/1884/45470

ARAUJO, Danielle Regina Wobeto de; VALLE, Gabrielle Stricker do. Processo dos Delitos e das Heresias: um guia de leitura das Ordenações Filipinas (1603) e do Regimento Inquisitorial de 1640. Porto Alegre: Editora Fi. 2019. https://www. editorafi.org/593delitos

BARROS, José D’Assunção. O tratamento historiográfico de fontes dialógicas. Revista Expedições: Teoria da História \& Historiografia, Morrinhos, v. 3, n. 1, p. 9-37, 2012. https://www.revista.ueg.br/index.php/revista_geth/article/view/288

BAUER, Caroline. Fontes sensíveis de história recente. In: PINSKY, Carla Bassanezi; LUCA, Tania Regina (org.) O historiador e suas fontes. São Paulo: Contexto, 2009. p. 173-194.

BERNAL, José Sánchez-Arcilla. En torno al derecho indiano vulgar. Cuadernos de Historia del Derecho, Madrid, n. 1, p. 13-24, 1994. https://dialnet.unirioja.es/ servlet/articulo?codigo $=905903$ 
BOBBIO, Norberto. Teoria Geral do direito. 2 ed. São Paulo: Martins Fontes, 2008.

BRANDÃO, Claudio. Tipicidade e Interpretação no Direito Penal. Sequência, Florianópolis, v. 35, n. 68, p. 59-89, 2014. https://doi.org/10.5007/2177-7055.2013v35n68p59

BRETAS, Marcos Luiz. O crime na historiografia brasileira: uma revisão na pesquisa recente. BIB, Rio de Janeiro, n. 32, p. 49-61, 1991.

BRETAS, Marcos Luiz; GRUNER, Clóvis (orgs). Apresentação. Revista História: Questões e debates, Curitiba, vol. 64, n. 1, jan./jun., 2016. https://doi.org/10.5380/ his.v64i1.47670

BRIGHENTE, Liliam Ferraresi. A condição jurídica criminal do escravo no Império do Brasil: um estudo a partir de Castro, província do Paraná (1850-1888). Tese (Doutorado em Direito) - Universidade Federal do Paraná, Curitiba, 2019. https:// acervodigital.ufpr.br/handle/1884/62347

BOURDÉ, Guy; MARTIN, Hervé. As Escolas Históricas. Lisboa: Publicações Europa-América, 1990.

BUENO, Almir de Carvalho. Processos-crime e micro-história: perspectivas e limitações em um estudo de caso. Mneme - Revista de humanidades, Caicó, v. 14, n. 32, p. 1-12, 2013. https://periodicos.ufrn.br/mneme/article/view/5422

BUSATO, Paulo Cesar. Direito Penal: parte geral. v. 1. 4. ed. rev. ampl. Curitiba: Atlas, 2018.

BUSATO, Paulo Cesar; CAVAGNARI, Rodrigo. Tipicidade penal finalista e tipo de ação significativo. Revista Justiça e Sistema Criminal, v. 9, n. 16, p. 147-180, 2017. https://revistajusticaesistemacriminal.fae.edu/direito/article/view/101/87

CABRAL, Gustavo César Machado. Literatura jurídica na idade moderna: as decisiones no reino de Portugal (séculos XVI e XVII). Rio de Janeiro, 2017.

CANTISANO, Pedro; PAES, Mariana Armond Dias. Apresentação: Processos judiciais e escrita da história na América Latina. Varia História, Belo Horizonte, v. 37, n. 74, p. 353-360, 2021. https://doi.org/10.1590/0104-87752021000200002

CASTELNAU-L'ESTOILE, Charlotte de. Páscoa Vieira, diante da Inquisição. Uma escrava entre Angola, Brasil e Portugal. Rio de Janeiro: Bazar do Tempo, 2020.

CAULFIELD, Sueann. Em defesa da honra: moralidade, modernidade e nação no Rio de Janeiro (1918-1940). Campinas: Unicamp, 2000.

CHALHOUB, Sidney. Trabalho, lar e botequim: o cotidiano dos trabalhadores do Rio de Janeiro na Belle Epoque. São Paulo: Brasiliense, 2001. 
CORREA, Mariza. Morte em família: representações jurídicas de papeis sexuais. Rio de Janeiro: Graal, 1983.

CRENSHAW, Kimberlé Williams. Documento para o encontro de especialistas em aspectos da discriminação racial relativos ao gênero. Revista Estudos Feministas, Florianópolis, v. 10, n. 1, p. 171-188, 2002. https://doi.org/10.1590/ s0104-026x2002000100011

COSTA, Pietro. O Estado de Direito: uma introdução histórica. In: COSTA, Pietro; ZOLO, Danilo (org.). O Estado de Direito: história, teoria, crítica. São Paulo: Martins Fontes, 2006. p. 95-198.

COSTA, Pietro. O conhecimento do passado: dilemas e instrumentos da historiografia. Curitiba: Juruá, 2007.

COSTA, Pietro. Discurso jurídico e imaginação: hipóteses para uma antropologia do jurista. In: PETIT, Carlos (org.). Paixões do Jurista: amor, memória, melancolia, imaginação. Curitiba: Juruá, 2011. p. 167-226.

DANTAS, Monica Duarte; NICOLETTI, Filipe Ribeiro. A importância dos acervos judiciais para a pesquisa em história: um percurso. Cultlex, Rio de Janeiro, v. 4, n. 2 , p. 47-87, 2020. http://lexcultccjf.trf2.jus.br/index.php/LexCult/article/view/418.

DUVE, Thomas. Was ist >Multinormativität $<$ - Einführende Bemerkungen. Rechtsgeschichte - Legal History, Frankfurt, n. 25, p. 88-101, 2017. https://doi. org/10.12946/rg25/088-101

FARGE, Arlette. O sabor do arquivo. São Paulo: Edusp, 2009.

FAUSTO, Boris. Crime e cotidiano. A criminalidade em São Paulo (1880-1924). São Paulo: Brasiliense, 1984.

FERRAJOLI, Luigi. Direito e razão: teoria do garantismo penal. 3. ed. São Paulo: Editora Revista dos Tribunais, 2002.

FERRAZ JR., Tercio Sampaio. Introdução ao estudo do direito: técnica, decisão, dominação. 5 ed. São Paulo, Atlas, 2007.

FONSECA, Ricardo Marcelo. Introdução teórica à História do Direito. Curitiba: Juruá, 2009.

FURMANN, Ivan. Cultura jurídica e transição entre Colônia e Império: a experiência da Ouvidoria de Paranaguá e Curitiba. Dissertação (Mestrado em Direito) Universidade Federal do Paraná, Curitiba, 2013. https://acervodigital.ufpr.br/ handle/1884/32532 
GARAPON, Antoine. Bem Julgar: ensaio sobre o ritual judiciário. Direito e Direitos do Homem, 9. Lisboa: Instituto Piaget, 1997.

GINZBURG, Carlo. Mitos, emblemas, sinais: morfologia e história. São Paulo: Companhia das Letras, 1989.

GINZBURG, Carlo. O Inquisidor como antropólogo: uma analogia e as suas implicações. In: GINZBURG, Carlo, CASTELNUOVO, Enrico; PONI, Carlo. A micro-história e outros ensaios. Rio de Janeiro: Bertrand Brasil, 1991.

GINZBURG, Carlo. Relações de Força: história, retórica, prova. São Paulo: Companhia das Letras, 2002.

GINZBURG, Carlo. O queijo e os vermes. 5 reimpr. São Paulo: Companhia das Letras, 2011a.

GINZBURG, Carlo. Controlando a evidência. In: NOVAIS, Fernando; SILVA, Rogério F. da (orgs.). Nova história em perspectiva. São Paulo: CosacNaif, 2011b.

GRINBERG, Keila. A história nos porões dos arquivos judiciários. In: PINKY, Carla Bassanezi; LUCA, Tania Regina (org.) O historiador e suas fontes. São Paulo: Contexto, 2009.

GROSSI, Paolo. El orden jurídico medieval. Madrid: Marcial Pons, 1996.

GROSSI, Paolo. História da propriedade e outros ensaios. Rio de Janeiro: Renovar, 2006 .

GROSSI, Paolo. Primeira lição sobre direito. Rio de Janeiro: Forense, 2006b.

HART, Herbert L. A. O conceito de direito. 2. ed. Lisboa: Fundação Calouste Gulbenkian, 1994.

HESPANHA, António Manuel. Categorias: um pouco de teoria da história. In: HESPANHA, António Manuel. Imbecillitas: as bem-aventuranças da inferioridade nas sociedades do Antigo Regime. São Paulo: Annablume, 2010a.

HESPANHA, António Manuel. Rústicos. In: HESPANHA, António Manuel. Imbecillitas: as bem-aventuranças da inferioridade nas sociedades do Antigo Regime. São Paulo: Annablume, 2010b, p. 141-198.

HESPANHA, António Manuel. O caleidoscópio do direito. O direito e a justiça nos dias de hoje. 2. ed. Coimbra: Almedina, 2009.

HESPANHA, António Manuel. Cultura Jurídica Europeia: síntese de um milênio. 3. ed. Lisboa: Europa-América, 2005. 
LACAPRA, Dominick. O queijo e os vermes: o cosmo de um historiador do século XX. Topoi, Rio de Janeiro, v. 16, n. 30, p. 293-312, 2015. https://doi. org/10.1590/2237-101X016030011

LACCHÈ, Luigi. “Não Julgueis”: antropologia da justiça e figuras da opinião pública entre os séculos XIX e XX. Belo Horizonte: Lafayette, 2020.

LOPES, José Reinaldo de Lima. Curso de Filosofia do direito. O direito como prática. São Paulo: Atlas, 2021.

LOPES, José Reinaldo de Lima. História da justiça e do processo no Brasil do século XIX. Curitiba: Juruá, 2017.

MACCORMICK, Neil. Retórica e o Estado de Direito. São Paulo: Elsevier, 2008.

MARQUES, José Frederico. Da Tipicidade Penal. Instituto dos Advogados de São Paulo. Conferência realizada em 03/11/1950, no Curso de Especialização em Direito Penal. http://www.revistajustitia.com.br/revistas/892735.pdf

NOBRE, Marcos. Apontamentos sobre a pesquisa em direito no Brasil. Cadernos direito GV, p. 1-19, 2009. http://hdl.handle.net/10438/2779

PAES, Mariana Armond Dias. Escravidão e direito. O estatuto jurídico dos escravos no Brasil oitocentista (1860-1888). São Paulo: Alameda, 2019.

PEREIRA, Luís Fernando Lopes. A circularidade da cultura jurídica: notas sobre o conceito e sobre o método. In: FONSECA, Ricardo Marcelo. Nova História Brasileira do Direito: ferramentas e artesanias. Curitiba: Juruá, 2012.

PEREIRA, Luís Fernando Lopes. Estruturas político-jurídicas na América Portuguesa: entre centro e periferia. In: I Congresso Latino Americano de História do Direito, 2008, Puebla, México. Anais..., Puebla, 2008.

PEREIRA, Luís Fernando Lopes. Discurso histórico e direito. In: FONSECA, Ricardo Marcelo (org.). Direito e discurso. Florianópolis: Boiteux, 2006.

ROSEMBERG, André, SOUZA Luís Antônio Francisco de. Notas sobre o uso de documentos judiciais e policiais como fonte de pesquisa histórica. Revista Patrimônio e Memória, Assis, v. 5, n. 2, p. 159-173, 2009. http://pem.assis.unesp.br/ index.php/pem/article/view/175/534

SABADELL, Ana Lucia. Manual de sociologia jurídica. Introdução a uma leitura externa do direito. 7. ed. rev. ampl. São Paulo: Revista dos Tribunais, 2017. 
SBRICCOLI, Mario. História do Direito e História da Sociedade: questões de método e problema de pesquisa. Revista Sequência, Florianópolis, n. 82, 2019. p. 288-312. https://doi.org/10.5007/2177-7055.2019v41n82p288

SBRICCOLI, Mario. Fontes judiciárias e fontes jurídicas. Reflexões sobre a fase atual dos estudos de história do crime e da justiça criminal. In: NUNES, Diego (org.). Estudos em história do direito penal e da justiça criminal. Uberlândia: LAECC, 2020. https://doi.org/10.12818/p.0304-2340.2019v74p135

SILVA, Luisa Stella de Oliveira Coutinho. Nem teúdas, nem manteúdas: História das Mulheres e Direito na capitania da Paraíba (Brasil, 1661-1822). Frankfurt am Main: Max Planck Institute for European Legal History, 2020. https://doi. org/10.12946/gplh15

SIQUEIRA, Gustavo. Pequeno Manual de Metodologia da Pesquisa Jurídica: Roteiro de pesquisa para estudantes de Direito. Belo Horizonte: Instituto Pazes, 2020.

SIROTTI, Raquel Razente. Direito penal e política na Primeira República: uma análise dos processos judiciais relacionados à tentativa de assassinato de Prudente de Morais em 1897. Varia História, Belo Horizonte, v. 37, n. 74, p. 429-462, 2021. https://doi.org/10.1590/0104-87752021000200005

VAINFAS, Ronaldo. História das mentalidades e história cultural. In: VAINFAS, Ronaldo; CARDOSO, Ciro Flamiron. Domínios da História. 2. ed. São Paulo: Elservier, 2011. 


\section{Additional information and author's declarations (scientific integrity)}

Acknowledgement: We thank our dearly missed Prof. Dr. António Manuel Hespanha, whose reflections and incentives encourage a large community of legal historians, including this present article. We also express our gratitude to Prof. Dr. Luis Fernando Lopes Pereira, who guided our methodological path in the treatment of the processes as a historical source.

Conflict of interest declaration: the authors confirm that there are no conflicts of interest in conducting this research and writing this article.

Declaration of authorship: all and only researchers who comply the authorship requirements of this article are listed as authors; all coauthors are fully responsible for this work in its entirety.

- Danielle Regina Wobeto de Araújo: conceptualization, methodology, data curation, investigation, writing - original draft, validation, writing - review and editing, final version approval.

- Gabrielle Stricker do Valle: conceptualization, methodology, writing and validation - review and editing, final version approval.

Declaration of originality: the authors assure that the text here published has not been previously published in any other resource and that future republication will only take place with the express indication of the reference of this original publication; they also attest that there is no third party plagiarism or self-plagiarism. 
Editorial process dates

(http://www.ibraspp.com.br/revista/index.php/RBDPP/about/editorialPolicies)

- Submission: 15/05/2021

Editorial team

- Desk review and plagiarism check: 01/06/2021

- Editor-in-chief: 1 (VGV)

- Review 1: 08/06/2021

- Review 2: 08/06/2021

- Review 3: 22/06/2021

- Associated-editor: 1 (RS e MG)

- Reviewers: 3

- Preliminary editorial decision: 30/06/2021

- Correction round return: 19/07/2021

- Final editorial decision: 19/07/2021

\section{HOW TO CITE (ABNT BRAZIL):}

ARAÚJO, Danielle R. W.; VALLE, Gabrielle S. O fio de Ariadne: um mapa metodológico para o labirinto das narrativas do processo criminal. Revista Brasileira de Direito Processual Penal, vol. 7, n. 2, p. 1187-1224, mai./ago. 2021. https://doi.org/10.22197/rbdpp.v7i2.576

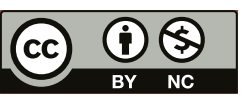

Esta obra está licenciada com uma Licença Creative Commons Atribuição-NãoComercial 4.0 Internacional. 